\title{
Self medication among hospitalized patients in selected secondary health facilities in South Western Nigeria
}

\author{
Titilayo O. FAKEYE, Razaq ADISA, Eniola OLATUNJI.
} Received (first version): 2-Jun-2010 Accepted: 8-Sep-2010

\begin{abstract}
${ }^{*}$
Practice of self-medication has not been evaluated in hospitalized patients especially in Nigerian hospitals.

Objectives: To evaluate the practice of selfmedication among hospitalized patients with an aim to unearth some of the reasons for, and perceptions of benefits of this type of behaviour in secondary health care facilities.

Methods: This study was carried out among 197 inpatients admitted in three secondary health facilities in southwestern Nigeria using structured questionnaire. Effects of variables such as age, gender and marital status on the practice of self medication were also evaluated using the Fisher's Exact test at $p<0.05$ as level of significance. Results: Response rate of the study was $93.8 \%$ with 174 respondents $(88.3 \%)$ perceived that the medications prescribed for them were efficacious. Almost $38 \%$ of the respondents were selfmedicating, with herbal medicines $(29.2 \%)$ and western medicines (37\%) partly due to side effects of the prescribed medicines. Thirty one (15.7\%) respondents obtained medicines for self medication through relatives and friends. Prescription medicines used for self medication constituted $7.5 \%$. Major reasons given for self medication included habit, availability and necessity. Ninety respondents $(35.7 \%)$ had been informed by health care personnel about possible side effects of the medications. Ninety six respondents (48.7\%) experienced side effects with the prescribed medications and was a major reason for self medication. Seventy six respondents $(79.2 \%)$ who had side effects or other secondary symptoms informed healthcare personnel in the hospital while $16(16.7 \%)$ informed relatives and friends. There was statistically significant association between age and the action taken on whom was informed $(\mathrm{p}=0.001)$.

Conclusions: There is need for extra vigilance from health personnel directly responsible for care of hospitalized patients to look for incidences of selfmedication and patient education on the negative aspects of administering undisclosed medicines to
\end{abstract}

*Titilayo O. FAKEYE. B.Pharm; PhD. Department of Clinical Pharmacy \& Pharmacy Administration. University of Ibadan. Ibadan (Nigeria).

Razaq ADISA. B.Pharm, M.Pharm. Department of Clinical Pharmacy \& Pharmacy Administration. University of Ibadan. Ibadan (Nigeria).

Eniola OLATUNJI. B.Pharm. Department of Clinical Pharmacy \& Pharmacy Administration. University of Ibadan. Ibadan (Nigeria). their health care givers especially while they are hospitalized.

Keywords: Self Medication. Inpatients. Nigeria.

\section{AUTO-MEDICACIÓN ENTRE PACIENTES \\ HOSPITALIZADOS EN \\ ESTABLECIMIENTOS SECUNDARIOS SELECTOS EN EL SUR OESTE DE NIGERIA}

\section{RESUMEN}

La práctica de la auto-medicación no ha sido evaluada en los pacientes hospitalizados, especialmente en Nigeria.

Objetivos: Evaluar la práctica de auto-medicación entre pacientes hospitalizados con el objetivo de desenterrar algunos motivos y percepciones del beneficio de este comportamiento en establecimientos de cuidados secundarios. Métodos: Este estudio fue realizado entre 197 pacientes hospitalizados en tres establecimientos de cuidados secundarios en el suroeste de Nigeria utilizando un cuestionario estructurado. También se evaluó, utilizando la prueba exacta de Fischer con $\mathrm{p}<0,05$ como nivel de significación, el efecto sobre la práctica de auto-medicación de variables como edad, género, estado civil.

Resultados: La tasa de respuesta del estudio fue del $93,8 \%$ con 174 respondentes $(88,3 \%)$ que percibían que los medicamentos prescritos eran eficaces para ellos. Casi el 38\% de los respondentes se automedicaban, el $29,2 \%$ con plantas medicinales y el $37 \%$ con medicinas occidentales, en parte debido a los efectos secundarios de los medicamentos prescritos. $31(15,7 \%)$ de los respondentes obtenía los medicamentos para auto-medicación de sus parientes y amigos. De los medicamentos de automedicación, el 7,5\% eran medicamentos de prescripción. Las principales razones aportadas para la auto-medicación incluían la costumbre, la disponibilidad y la necesidad. 90 respondentes $(35,7 \%)$ habían sido alertados por el personal sanitario de los posibles efectos secundarios de los medicamentos. $96(48,7 \%)$ experimentó efectos secundarios de la medicación prescrita y esta fue la principal razón para la auto-medicación. 76 $(79,2 \%)$ de los que habían tenido efectos secundarios informaron al personal sanitario del hospital, mientras que $16(16,7 \%)$ que tuvo efectos secundarios u otros síntomas secundarios informó a sus parientes y amigos. Hubo una asociación estadística entre la edad y la acción tomada sobre quien era informado $(\mathrm{p}=0,001)$. 
Concusiones: Existe una necesidad de una vigilancia extra del personal sanitario directamente responsable de los cuidados de los pacientes hospitalizados para localizar la aparición de automedicación y de la educación de los aspectos negativos de la administración de medicamentos no declarada a sus profesionales de la salud, especialmente mientras están hospitalizados.

Palabras clave: Auto-medicación. Pacientes hospitalizados. Nigeria.

\section{INTRODUCTION}

The World Health Organization (WHO) defines self medication as the selection and use of medicines by individuals to treat self recognized illness or symptoms. ${ }^{1}$ The World Self Medication Industry which is a federation representing manufacturing and distributors of non-prescription drugs and who also try to support development of responsible self medication, similarly defines it as the treatment of common health problems with medicines specially designed and labeled for use without medical supervision and approved as safe and effective for such use.

Self medication is an element of self care. ${ }^{1}$ It is a growing trend which has had the approval of the WHO for the effective and quick relief of symptoms for minor ailments without medical consultations. This is to reduce burden on health care services especially in understaffed, inaccessible rural or remote areas. $^{3}$ Medicines approved for self medication are expected to be of proven quality, safety and efficacy, and should be for indications that are self recognizable, and may also be used for some chronic and recurrent conditions following initial medical diagnosis.

The decision to seek self medication is complex and depends on a blend of predisposing (symptoms that require treatment), enabling (easy accessibility to medicines for self medication) and attitudinal (habit or ambivalence) variables. The increase in the use of certain alternative therapies such as herbal medicine might have contributed to increases in adverse reactions due to co administration of conventional and herbal medicines without the supervision of qualified health practitioners. The recent increases in consultation and health care charges in some parts of the world have been given as reasons for patients targeting more affordable alternatives such as herbal medicines to treat or prevent their own ailments. ${ }^{4}$ The incidence of self medication is widespread with no significant difference between underdeveloped, developing and developed nations. Literature shows a high incidence of self medication with over-the-counter, complementary and sometimes prescriptions medicines in a range of $15.0-81.5 \%$ in different localities. ${ }^{3-11}$ In Singapore, the populace are advised to be cautious vis a vis purchasing medicinal products from dubious sources such as the internet, and to beware of exaggerated health benefits and unrealistic personal testimonials accompanying medicines and health products. Patients have also been advised to seek professional medical advice when self medicating. ${ }^{12}$ In most studies, patients were unaware of the possibility of interactions, and community pharmacists were not vigilant enough to alert their clients of the potential interactions with other drugs. ${ }^{10}$

A large number of the studies evaluating incidences of self medication among in-patients had been carried out in developed countries. ${ }^{13,14}$ Literature on studies assessing self medication by in-patients in developing countries where there is easier access to medicines (prescription or over-the-counter) without prescription such as Nigeria is very scanty. To the best of our knowledge, studies of this type have not been carried out in Nigeria except for Fakeye et al. ${ }^{15}$ which evaluated the use of herb mainly by out-patients in some health care facilities in Nigeria. Pilot studies by the authors showed that self medication is a problem in Nigeria due to easy and illegal access to prescription and controlled medicines without prescription. The present study is focused on evaluating the incidence of self medication among hospitalised patients whose medicines while in the hospital should strictly be prescribed and administered by approved health care personnel under whose care they were. This study was carried out in secondary health facilities in Nigeria to evaluate the patient's perception of the benefits of this type of behavior.

\section{METHODS}

Study site

Oyo State is one of the most populated states in Nigeria with a mixture of people of varying socioeconomic status. The three hospitals used as sites for the study were government-owned. The study was carried out between February and May, 2008, after approval had been obtained from the Ethics Review Committee of the Oyo State Health Management Board. Three secondary government health care facilities situated in the state capital with a total of 455 beds were used as study sites. One of them is a maternity hospital while one of them is known as a center for the treatment of tuberculosis and cholera infections and the third is a general hospital.

All the wards in the hospitals except children wards were used. In each hospital, the respondents/patients were selected randomly. Where applicable every second patient in the selected wards was enrolled based on the calculated sample size. Where, for reasons of mental incompetence or disinterest in the study a patient could not be selected, the patient on the next bed was enrolled.

Inclusion criteria:

Two hundred and ten hospitalized patients [according to calculated sample size using Raosoft SampleSize Calculator (http://www.raosoft.com/samplesize.html) at $5 \%$ 
level of error and $95 \%$ confidence level] who had been on admission for more than two weeks prior to the study were selected and recruited. Their consent to participate in the study was sought and obtained after the study had been fully explained to them. The selected respondents were not less than 18 years of age, conscious and judged to be mentally alert. Children below the age of 18 years were not selected.

Self medication was defined for this study as the act of using medication that was not prescribed by the physician or other such persons that are qualified in the hospital while the patient is on admission. Any drug taken while on admission that is different from the one(s) prescribed by an attending physician in the hospital is taken as an act of self medication even if prescribed by a family member, friend or acquaintance that is qualified to prescribe or recommend drugs.

Structured questionnaire was used to evaluate practice of self medication among in-patients. The instrument which took about thirty minutes to complete contained mostly close-ended questions. Demographic data and responses of patients on their perception of efficacy of the medicines they were placed while on admission, unwanted effects observed with use of the medicines, steps taken when such secondary illnesses were noticed, use of medicines and herbs that were not prescribed while on admission, and how they were obtained were gathered.

Pretesting and validation of the questionnaire was done by administering the questionnaire to pharmacists and in-patients from another hospital in the area respectively. After pretesting, definition of self medication was redone to include use of medicines recommended by a relative or friend that is a health practitioner. The questionnaires were self-administered by respondents that could read and speak English. Patients who were unable to fill the questionnaire themselves were assisted to do so by the investigators. Due to the low number of divorced and widowed respondents involved in the study, they were merged and the group referred to as divorced/widowed.

Statistical analysis of the data obtained was done on GraphPadlnStat. Descriptive statistics were used to determine frequency of the responses and variables while contingency tables were used to establish positive or negative association between the respondents' response and their demographic variables using Fisher's exact test. Level of significance was set at $p<0.05$.

\section{RESULTS}

Responses from a total of 197 (94.3\%) respondents were found fit for analysis. The demographic data is as shown in Table 1 . Seventy four respondents $(37.6 \%)$ were self medicating with herbs or conventional over-the-counter and prescription medicines, out of which twenty eight respondents $(29.2 \%)$ were on herbal medicines while on admission. Thirty nine $(40.6 \%)$ respondents obtained the medication through advice or asking relatives/friends to purchase particular medicines/herbs. Thirty five (36.4\%) did not disclose how they obtained theirs. The content of most of the herbal medicines was not known. Respondents, who also did not know the contents, referred to them by their local names such as "abiye" (deliver safely), and "opa eyin", "jedi" (for pile/hemorrhoids, lower backache). There were some with known herbs such as lemon grass (Cymbopogon citratus). The herbs were used for back pain and dysentery which might have been side effects of conventional drugs or secondary symptoms that came up after they had been admitted in the hospital but were not disclosed to the physicians/nurses on the wards and "prophylaxis" for safe delivery of babies.

\begin{tabular}{|c|c|c|}
\hline Variable & Number & Frequency \\
\hline \multicolumn{3}{|l|}{ Sex } \\
\hline Male & 67 & $34 \%$ \\
\hline Female & 130 & $66 \%$ \\
\hline \multicolumn{3}{|l|}{ Marital Status } \\
\hline Single & 48 & $24.4 \%$ \\
\hline Married & 127 & $64.5 \%$ \\
\hline Widowed/Divorced & 22 & $11.2 \%$ \\
\hline \multicolumn{3}{|l|}{ Age } \\
\hline 18-25years & 49 & $24.8 \%$ \\
\hline 26-41years & 100 & $50.8 \%$ \\
\hline$>41$ years & 48 & $24.4 \%$ \\
\hline \multicolumn{3}{|l|}{ Education } \\
\hline Primary & 74 & $37.6 \%$ \\
\hline Secondary & 77 & $39.1 \%$ \\
\hline Tertiary & 46 & $23.4 \%$ \\
\hline \multicolumn{3}{|l|}{ Profession } \\
\hline Students & 31 & $15.7 \%$ \\
\hline Artisans & 128 & $65.0 \%$ \\
\hline White-collar workers & 28 & $14.2 \%$ \\
\hline Pensioners & 10 & $5.1 \%$ \\
\hline
\end{tabular}

Prescription medicines constituted $7.5 \%$ of medicines used for self medication (diazepam $4 \%$, salbutamol $0.5 \%$ and antibiotics/antibacterials 3\%). Over-the-counter drugs in different combinations such as paracetamol (26\%), aspirin (34\%), multivitamins and minerals $(6 \%)$, and vitamin $\mathrm{C}$ (3\%) were also used for self medication for secondary symptoms such as insomnia, pain and others which were obtained mainly through relatives. Respondents, who were involved in self medication, believed they were augmenting or complementing medical treatment given in the hospital and so did not need to inform the physicians, nurses or pharmacists. They were not aware that these medications could have adverse effects on the outcome of their treatment. Reasons given in different combinations include habit of treating themselves when there is a need $(30 ; 15 \%)$, availability through relatives and friends $10(5 \%)$ and necessity $(8 ; 4 \%)$. Perception of inadequate care $(2 ; 1 \%)$, affordability $(2 ; 1 \%)$ and accessibility $(1 ; 0.5 \%)$ were the other reasons given. Ninety six respondents $(48.7 \%)$ experienced side effects with the medicines including, in different combinations nausea $25(26.0 \%)$, increased appetite and frequent urination $25(26.0 \%)$, and headache, itching and stomach disorder 9 (9.4\%). Seventy four respondents $(77.0 \%)$ who had side effects or secondary symptoms post admission were involved in self medication. 
One hundred and seventy four respondents (88.3\%) perceived that the medicines prescribed for them were effective. A total of 90 patients had been sensitized by healthcare personnel in the hospital about potential side effects from the medications they were on, among which 37 respondents (41.1\%) had been informed by physicians, 51 (56.7\%) by nurses and $2(2.2 \%)$ by pharmacists. Seventy six respondents $(79.2 \%)$ who experienced side effects to their medicines or who experienced other ailments outside their primary complaints informed at least an healthcare personnel in the hospital while 16 (16.7\%) informed non-health care personnel such as relatives and friends who came visiting. Others $(8 ; 4.1 \%)$ did nothing about it. There was statistically significant association between age of the respondents and the action taken on whom was informed $(p<0.001)$ about perceived incidence of secondary symptoms. A low percentage of singles, $10(20.8 \%)$, at the lower end of age bracket (18-24 years) informed health care personnel about secondary symptoms and/or side effects observed. There was no significant association between the other variables such as sex and the action taken on who was informed when there were secondary symptoms that needed to be taken care of.

A high percentage, 110 (55.8\%) thought they had an extended stay in the hospital. Out of the remaining, 87 (44.2\%), twenty-one (24.1\%) were not sure if their stay had been extended or not. Reasons given to patients for extension of stay in the hospital included slow response to treatment, lack of fund to settle hospital bills or purchase drugs, unavailability of blood needed for transfusion, and awaiting appropriate stabilization before surgery.

\section{DISCUSSION}

There were twice more females than males probably because one of the hospitals used for the study is a maternity hospital.

The ailments for which self medication was being done in this study were minor ailments such as pain, headache, stomach disorder corroborating earlier studies by Goh et al. ${ }^{4}$, Hardon \& van der Geest $^{5}$ and Ruebush et al. ${ }^{7}$ in which perceived severity of disorders influences self medication practice. Easy accessibility to controlled medications also makes self medication easy for some of the respondents since there were no stringent controls of sale of prescription medicines in Nigeria. A lot of prescription-status medicines can be obtained without prescriptions in Nigeria. Previous studies showed that making several drugs available (such as changing prescription medicines status to over-the-counter or not having good regulatory controls over prescription medicines) to consumers may also contribute to the problems associated with self medication. ${ }^{4}$ This might have had an influence on the use of prescription medicines such as diazepam, antibiotics and salbutamol for self medication in the present study.

Also used for self medication in this study were herbal medicines, the contents of most of which were not known. Informing the health care personnel of the use of herbs by these respondents might not have made much difference since counseling could not be adequately done as the contents were not known. A study carried out showed that there are higher chances of self medicating with an herbal medicine than over-thecounter or prescription medicine ${ }^{16}$ due to the perceived efficacy of herbal medicines. Self medication is generally associated with risks such as misdiagnosis, use of excessive drug dosage, prolonged duration of use, drug interactions and polypharmacy. ${ }^{17}$ There have been reports of patients self medicating with over-the-counter drugs with potential and real interactions. ${ }^{10,18}$ The problem may be compounded by unawareness of professionals $^{14}$ such as physicians and nurses taking care of the patients in the wards.

Age also played a role in the issue of self medication among this group of patients. There was statistically significant association between age and the category of person (health care personnel versus non-health personnel) informed on the secondary symptoms experienced. Respondents who were single informed more of their families and friends than health care personnel that were present. Studies in Spain and Nepal ${ }^{19,20}$ showed a tendency for undesirable self medication with respondents 40 years of age and below, respondents who live alone or students than other groups of people.

Even though most respondents were satisfied with the perceived efficacy of their medications, almost half complained of experiencing side effects with the drugs which was one of the reasons stated for self medication. Less than half of the respondents had been informed to expect some side effects from the medicines. It was quite surprising to note that only $2.2 \%$ of the patients experiencing side effects had been informed by pharmacists compared with $56.7 \%$ by nurses and $41.1 \%$ by physicians. This was probably due to the organizational structure of such hospitals in which pharmacists rarely have contact with patients on admission due to nonclinical roles of majority of hospital pharmacists in Nigeria.

One of the factors that could have contributed to reasons for self medication while on admission is the issue of extended stay. Patients might be delayed in the hospital for several reasons. In this study, however most patients saw their extended stay as a result of unimproved health status. Some of the patients had extended stay because they could not settle their bills or could not purchase their drugs. Having an extension of stay was also perceived by some respondents as ineffectiveness of the therapy and might have possibly been a reason for self medication in some of the cases though this was not followed up.

This study was limited by the fact that we couldn't ascertain the costs of medicines used for self medication. Also, unlike other previous study, the names of the herbs used for self medication could not be obtained. Knowing the particular herb's name might have probably enabled us to link some of the 
reasons for the perceived prolonged stay or some experienced secondary illness of the respondents to the effects of the undisclosed herbs.

\section{CONCLUSIONS}

There is a need for healthcare professionals in hospital wards to make conscious effort to investigate possible use of non-prescribed drugs by patients who are admitted in the hospital and a need for a more rigorous medication history taken when patients are to be admitted to unearth use of over-the-counter, herb, and prescription medicines that are not known to the physician/pharmacist prior to admission. Patients need to be encouraged to promptly report secondary symptoms or side effects to the appropriate health personnel rather than self medicate with medicines not approved by the attending physicians.

\section{CONFLICT OF INTEREST}

The authors declare no conflict of interest.

\section{References}

1. World Health Organisation. The Role of the pharmacist in self-care and self-medication. Reports of the 4th WHO Consultative Group on the Role of the Pharmacist. The Hague, The Netherlands. 26th -28th August 1998. WHO/DAP/98.13.

2. World Health Organization. Responsible self-care and self-medication; A worldwide review of consumers' survey; the World Self-Medication Industry. http://www.wsmi.org. Accessed 27th April, 2010

3. Phalke VD, Phalke DB, Durgawale PM. Self medication practices in rural Maharashtra. Indian J Community Med 2006;31(1):34-35.

4. Goh LY, Vitry AI, Semple SJ, Esterman A, Luszcz MA. Self-medication with over-the-counter drugs and complementary medications in South Australia's elderly population. BMC Complement Altern Med 2009;9:42.

5. Hardon A, Van der Geest S. Hazards of self-medication. Drugs - World Health Forum 1987;8:469-471.

6. Saeed AA. Self medication among primary care patients in Faradak Clinic in Riyadh. Soc Sci Med 1988;27:287-289.

7. Ruebush TK, Kern MK, Campbell CC, Oloo AJ. Self treatment of malaria in a rural area of western Kenya. Bull World Health Organ 1995;73(2):229-236.

8. Ibrahim MIM. Treating one's own ailments. Primary Health Care, World Health Forum 1996;17:409-410.

9. Durgawale PM. Practice of self-medication among slum dwellers. Indian J Pub Health. 1998;42:53-55.

10. Indermitte J, Reber D, Beutler M, Brunacher R, Hersberger KE. Prevalence and patient awareness of selected potential drug interactions with self medication. J Clin Pharm Ther. 2007;32(2):149-159.

11. World Health Organisation. Self-medication and its impact on essential drug schemes in Nepal: a socio-cultural research project. EDM Research Series No 10. WHO/DAP/93.10.

12. World Health Organization. Caution on self-medication In: Regulatory Action and News, WHO Drug Information 2005; 19(3), 201-242 (Press Release 17th June, 2005. http://www.hsa.gov.org)

13. Batty GM, Oborne CA, Swift CG, Jackson SH. The use of over-the-counter medication by elderly medical in-patients. Postgrad Med J. 1997;73(865):720-722.

14. Oborne CA, Lucaz ML. Over-the-counter medicine use prior to and during hospitalization. Ann Pharmacother. 2005;39(2):268-273.

15. Fakeye TO, Abu T, Adebisi O. A Survey of the Use of Herbs Among Patients Attending Secondary-Level Health Care Facilities in Southwestern Nigeria. J Herbal Pharmacother. 2008;7(3\&4):213-227.

16. Lynch N, Berry D. Differences in perceived risks and benefits of herbal, over-the-counter conventional, and prescribed conventional, medicines, and the implications of this for the safe and effective use of herbal products. Complement Ther Med. 2007;15(2):84-91.

17. Hughes CM, McElnay JL, Fleming GF. Benefits and risks of self medication. Drug Saf. 2001;24(14):1027-1037.

18. Michel RH, Neafsey PJ, Cox Dzurec L. Self medication practices among patients taking levothyroxine. Internet J Adv Nurs Pract 2004;6(2). Accessed on the 27th April, 2010.

19. Figueiras A, Caamano F, Gestal-Otero J. Sociodemographic factors related to self-medication in Spain. Eur J Epidemiol. 2000;16(1):19-26.

20. Shankar PR, Partha P, Shenoy N. Self-medication and non-doctor prescription practices in Pokhara valley, Western Nepal: a questionnaire-based study. BMC Fam Pract. 2002;3:17. 